\title{
Reservoir souring: sulfur chemistry in offshore oil and gas reservoir fluids
}

\author{
Mahsan Basafa ${ }^{1}$ (D) Kelly Hawboldt ${ }^{1}$
}

Received: 10 March 2018 / Accepted: 27 July 2018 / Published online: 4 August 2018

(c) The Author(s) 2018

\begin{abstract}
The injection of sulfate-containing seawater into an oil reservoir, for maintaining the reservoir pressure, can promote the growth of sulfate reducing bacteria and archaea near the injection wells, leading to the formation of sulfides such as hydrogen sulfide. However, intermediate sulfur species with different valence states, such as polythionates and polysulfides have been detected in several produced water samples, likely a result of phase partitioning, and chemical and microbial reactions. These sulfur species could affect the microbial communities (e.g., microbially influenced corrosion) and will impact the efficiency of souring mitigation methods. In addition, the presence of these sulfur species can result in operational, environmental, and treatment problems. Therefore, development and implementation of souring control strategies during production cycle of oil and gas reservoirs require identifying the origins, reactivity, and the partitioning behaviour of these compounds. This paper presents an overview of the known mechanisms responsible for reservoir souring and then focuses on the chemical reactions and sulfur species associated with production and consumption of hydrogen sulfide. In this work we highlight complexity of the sulfur chemistry and that the assumption that all the sulfate is reduced to hydrogen sulfide can lead to inappropriate souring management methods. The paper also reviews the detection and analysis methods used for sulfur compounds. The review demonstrates that there is a gap in the current souring models and methods due to the exclusion of key sulfur compounds and challenges in identifying and quantifying these compounds with respect to speed of analysis and sample stability.
\end{abstract}

Keywords Chemical reactions $\cdot$ Hydrogen sulfide $\cdot$ Sour reservoirs $\cdot$ Sulfur chemistry $\cdot$ Analytical methods

\section{Introduction}

The injection of sulfate-containing seawater for maintaining the pressure of oil reservoirs can promote the growth of sulfate reducing bacteria (SRB) and archaea near the injection wells, leading to the reduction of sulfate to sulfide (Holubnyak et al. 2011; Khatib and Salanitro 1997; Stemler 2012; Voordouw et al. 2007; Kaster et al. 2007; Machel 2001; Hubert 2010). Subsequent biologically and chemically mediated reactions result in the formation of elemental sulfur as well as other reduced sulfur compounds. The analysis of produced water samples has shown the presence of other sulfur species such as thiosalts, sulfite, and polysulfides along with sulfide (Witter and Jones 1998; Boulegue et al. 1981). The average oxidation state of these sulfur species is

Mahsan Basafa

mahsan.basafa@mun.ca

1 Faculty of Engineering and Applied Science, Memorial University of Newfoundland, St. John's, Canada between that of sulfate-sulfur $(+6)$ and sulfidic-sulfur $(-2)$, and therefore, they are usually referred to as intermediate sulfur species (Fig. 1). These intermediate sulfur species have implications in both chemical and microbial processes and could impact the treatment approaches for soured reservoirs (Hissner et al. 1999; O'Reilly et al. 2001; Tang et al. 2009; Warren et al. 2008; Reid and Warren 2016). The reduced forms of sulfur appear in various oxidation-reduction (redox) reactions and can react with each other in the aqueous solution influencing the souring/scaling process. The level and types of sulfur species (i.e., sulfur speciation) is a function of reservoir temperature, pressure, $\mathrm{pH}$, and composition, therefore, as conditions change within flowlines and unit operations, these compounds could degrade to corrosion causing and health and safety problematic compounds, and impact effectiveness of the produced water and other treatment systems (Miranda-Trevino et al. 2013; Miranda-Trevino 2013; Witter and Jones 1998). The distribution of sulfur compounds is also important to determine 
Fig. 1 Oxidation reduction reactions in sulfur cycle

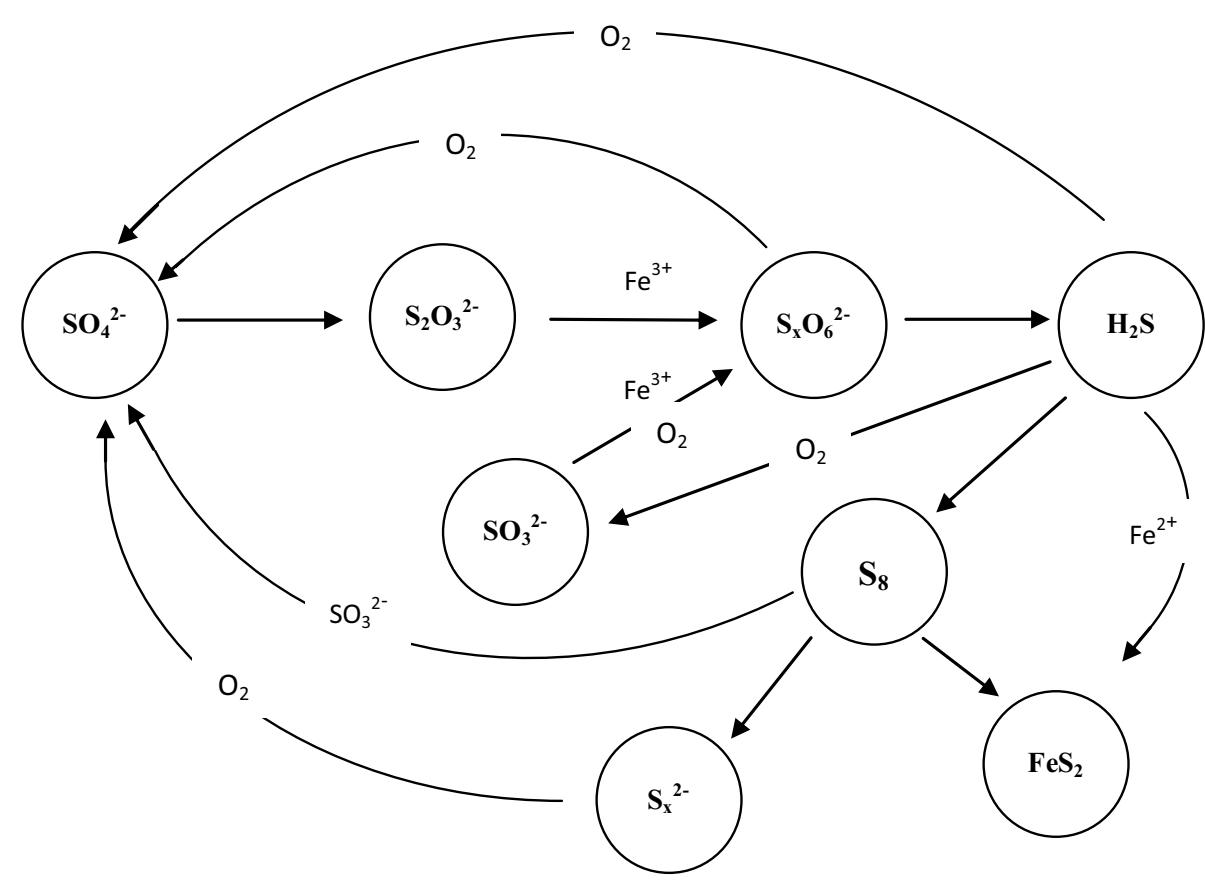

souring mitigation measures to either prevent the formation of sulfide or lowering the amount of sulfide already presents.

The role of intermediate sulfur species in biological activity is well documented (e.g. Tang et al. 2009). However, the chemical reactivity, which would affect the sulfur chemistry of the reservoir, topsides, and methods to control reservoir souring (e.g. nitrite injection) is less well understood. There is a gap in knowledge in sulfur chemistry (outside of the formation of hydrogen sulfide and some common sulfur species) in reservoirs where seawater is injected. The objective of this paper is to provide a comprehensive review of research findings in sulfur chemistry in oil reservoirs at low to moderate temperatures to highlight the importance of understanding the sulfur chemistry in determining the full extent of reservoir souring. The first step in studying sulfur speciation in oil reservoirs is to investigate the chemistry of hydrogen sulfide in a multiphase system. There are a number of biogenic and non-biogenic mechanisms that produce $\mathrm{H}_{2} \mathrm{~S}$ in reservoirs. Once generated within a reservoir, $\mathrm{H}_{2} \mathrm{~S}$ partitions between different phases present in the reservoir fluid. This partitioning behaviour is a function of temperature, pressure, $\mathrm{pH}$, salinity, and hydrocarbon composition. There are also other reduced sulfur species present in reservoir fluid which could impact $\mathrm{H}_{2} \mathrm{~S}$ distribution between phases. The reactivity of these compounds is complex and depends upon temperature, $\mathrm{pH}$, as well as the presence of other sulfur species, metals and microorganisms. The occurrence and behaviour of these intermediate sulfur species and their impact on $\mathrm{H}_{2} \mathrm{~S}$ distribution need to be studied for developing souring control strategies. As most souring management methods are developed based on models (for SRB induced souring) where the primary assumption is usually the production of only hydrogen sulfide from sulfate reduction. This can potentially result in ineffective souring management approaches. Therefore, in this work, we review the possible sulfur species that can be formed. We also detail the challenges in detection and analysis of sulfur compounds in oil and gas fluids.

\section{Reservoir souring and hydrogen sulfide formation}

At temperatures above $250{ }^{\circ} \mathrm{C}$, aqueous sulfate, derived from seawater, pore water, or from dissolution of solid calcium sulfate (mainly gypsum and anhydrite), can be reduced by a variety of organic compounds such as alcohols, polar aromatic hydrocarbons, and saturated hydrocarbons (Toland 1960; Kiyosu and Krouse 1990; Krouse et al. 1988; Machel 1987; Orr 1977; Belkin et al. 1985). This thermal redox reaction or thermochemical sulfate reduction (TSR) can result in high concentrations of $\mathrm{H}_{2} \mathrm{~S}$ in the reservoir fluid (more than $10 \%$ ). TSR is well documented in the field and experiments have been conducted to investigate the reactions involved, possible products, and the effect of temperature, type of oxidants, presence of sulfur species and metal cations, and the pH on the TSR rate (e.g. Orr 1977; Sassen 1988; Anderson and Machel 1988; Krouse et al. 1988; Heydari and Moore 1989; Ligthelm et al. 2000; Goldstein and Aizenshtat 1994; Worden et al. 1995, 1996, 2000; Chen et al. 2009; Hutcheon et al. 2009; Zhang et al. 2007, 2008; Amrani et al. 2008; Yuan et al. 2013). 
Thermolysis and/or aquathermolysis of aromatic thiophene-type organosulfur compounds such as thiophene and aliphatic organic sulfides such as tetrahydrothiophene in heavy oil also produces $\mathrm{H}_{2} \mathrm{~S}$ (Hoffmann and David 2018; Marcano et al. 2013; Clark et al. 1983, 1984b). Aquathermolysis reactions between oil and steam are dominant at temperatures below $240{ }^{\circ} \mathrm{C}$, while thermolysis (i.e., in the absence of water) dominates at higher temperatures. The amount of $\mathrm{H}_{2} \mathrm{~S}$ production by thermal decomposition of oil is proportional to the sulfur content of the oil and is typically less than $5 \%$. Thiols, sulfide, disulfides, polysulfides, thiophenes, benzothiophenes, and dibenzothiophenes are typical sulfur species in bitumen with disulfides and thiols the most reactive and benzothiophenic compounds the most stable sulfur species (Clark et al. 1983, 1984b).

Oxidative and reductive dissolution of metal sulfides under acidic conditions may also produce sulfate ions (a source for SRB growth) and $\mathrm{H}_{2} \mathrm{~S}$ during water flooding or steam injection (Marsland et al. 1989; Hutcheon 1998).

Oxidative dissolution : $\mathrm{MS}+4 \mathrm{H}_{2} \mathrm{O}+x \mathrm{O} \rightarrow \mathrm{M}^{2+}+\mathrm{SO}_{4}^{2-}$

$$
+8 \mathrm{H}^{+}+x \mathrm{R}
$$

Reductive dissolution : $\mathrm{MS}+2 \mathrm{H}^{+}+y \mathrm{R} \rightarrow \mathrm{M}^{2+}+\mathrm{H}_{2} \mathrm{~S}+y \mathrm{O}$

MS represents sulfide mineral, $\mathrm{M}$ is the metal base, and $\mathrm{O}$ and $\mathrm{R}$ are oxidized and reduced compounds in the redox reaction, respectively. The acidic components come from the injection water or the degradation of injected biocides and corrosion and scale inhibitors (Khatib and Salanitro 1997; $\mathrm{Xu}$ and Schoonen 1995). Iron sulfides, such as pyrite and pyrrhotite are common metal sulfide minerals associated with reservoirs forming under reducing conditions (Rickard et al. 1995). Pyrite is oxidized to sulfate and hydrogen reducing the $\mathrm{pH}$ of the environment (Hutcheon 1998; Rimstidt and Vaughan 2003). At pH values lower than 7, pyrite oxidation by dissolved oxygen produces tetrathionate and sulfate, while, at higher $\mathrm{pH}$ values, thiosulfate and sulfite are the major reaction products (Xu and Schoonen 1995). An increase in temperature is accompanied with an increase in the rate of pyrite oxidation and sulfate concentration. The rate of pyrite oxidation at $25{ }^{\circ} \mathrm{C}$ is rapid enough to be observed in a few years (Hutcheon 1998). The most favorable decomposition reactions for pyrite at low $\mathrm{pH}$ values $(\mathrm{pH}<7)$ and under reducing conditions, generating $\mathrm{H}_{2} \mathrm{~S}$ are (Peters 1976):

$$
\begin{aligned}
& \mathrm{FeS}_{2}+2 \mathrm{H}^{+} \rightarrow \mathrm{Fe}^{2+}+\mathrm{H}_{2} \mathrm{~S}+\mathrm{S}^{0} \\
& \mathrm{FeS}_{2}+4 \mathrm{H}^{+}+2 \mathrm{R} \rightarrow \mathrm{Fe}^{2+}+2 \mathrm{H}_{2} \mathrm{~S}+2 \mathrm{R}
\end{aligned}
$$

Under basic conditions, pyrite is decomposed to sulfate and sulfide, while, in the presence of an oxidant, it is converted to elemental sulfur (Peters 1976):
$\mathrm{FeS}_{2}+4 \mathrm{OH}^{-} \rightarrow 1 / 3 \mathrm{Fe}_{3} \mathrm{O}_{4}+11 / 6 \mathrm{~S}^{2-}+1 / 6 \mathrm{SO}_{4}^{2-}+2 \mathrm{H}_{2} \mathrm{O}$

$\mathrm{FeS}_{2}+2 \mathrm{O} \rightarrow \mathrm{Fe}^{2+}+2 \mathrm{~S}^{0}+2 \mathrm{O}$

Reservoir pores contain both water and hydrocarbons and as the hydrocarbon is produced, capillary forces result in water retention in the small pores of the reservoir rock. This initial water saturation may vary from 5 to $50 \%$ (Katz 1959; Standing 1977). This formation water has the capacity to absorb (from soured reservoir fluids) and potentially store $\mathrm{H}_{2} \mathrm{~S}$. As reservoir pressure decreases during production, the solubility of $\mathrm{H}_{2} \mathrm{~S}$ in water decreases, liberating formation water $\mathrm{H}_{2} \mathrm{~S}$ to the produced reservoir fluid. This is a potential mechanism for souring the fluids, even if souring mitigation measures have been put in place upstream. Seto and Beliveau observed this phenomena, in the Caroline field, where souring was attributed in part to the migration of $\mathrm{H}_{2} \mathrm{~S}$ from the aqueous phase in the reservoir (Seto and Beliveau 2000). This is an important phenomena, as it could in part explain the observation of $\mathrm{H}_{2} \mathrm{~S}$ in produced fluids even after a reservoir has been treated to prevent souring (e.g. nitrate injection).

Bacterial sulfate reduction (BSR), is a common and widespread process in shallow burial diagenetic settings, and considered "instantaneous" on a geological time scale leading to the generation of $\mathrm{H}_{2} \mathrm{~S}$. Biogenic sulfide production results in soured oil and gas in the reservoir and topside processing facilities including oil-water separation units, water storage tanks for produced water, and flowlines. There are various comprehensive reviews on the types of sulfate reducers (Barton and Fauque 2009; Muyzer and Stams 2008; Grigoryan et al. 2008; Bodtker et al. 2008; Wei et al. 2010; Agrawal et al. 2010; Orphan et al. 2000; Kumaraswamy et al. 2011), bioreaction mechanisms, products, and geochemical characteristics of BSR (Machel 1987, 1992; Machel et al. 1995; Noth 1997; Morse et al. 1987; Goldhaber and Orr 1995).

Anaerobic microorganisms that reduce sulfate are either indigenous in deep subsurface reservoirs or can be introduced into a reservoir during drilling operations or water flooding (Gieg et al. 2011). The latter has been found to be a source of multiple components including sulfate, carbon sources, and sulfate reducing communities that influence oilfield souring. The extent of microbial souring depends on the water-flooding operations (i.e. seawater injection or produced water re-injection) (Voordouw et al. 2009; Lysnes et al. 2009), salinity (Wilhelms et al. 2001; Stetter et al. 1993), temperature (Voordouw et al. 2009; Kaster et al. 2007), and sources of carbon and other nutrients (Grigoryan et al. 2008). 


\section{Oilfield souring control: chemical treatments}

Microbial activity offshore is managed by a number of different methods. Injection of biocides at the topside and/or to the injection water is the most common method. Biocides suppress microbial growth and activity, particularly in reservoirs where souring is confined to the zone around injection well (Gieg et al. 2011). Common biocides for controlling microbial activity include glutaraldehyde, tetrakis (hydroxymethyl) phosphonium sulfate (THPS), benzalkonium chloride, formaldehyde, and sodium hypochlorite (Videla and Herrera 2005; Kaur et al. 2009). Biocides are relatively simple to administer, however, continued use of them can lead to increase in biocide-resistant microbial communities. Biocides are potentially hazardous to oilfield personnel and the environment and difficult to inject deep into reservoir making treatment of SRB distant from injection well challenging.

Nitrate injection at the injection well or at the production well in the produced water treatment is an alternative to biocide treatment (Sunde et al. 2004; Sturman and Goeres 1999; Dolfing and Hubert 2017; Myhr et al. 2002). Unlike biocides, nitrate flows readily into an oil-bearing formation and shifts the microbial activity from SRB to nitrate reducing bacteria (NRB). The addition of nitrate into an injection well stimulates nitrate reducing bacteria (NRB), which are responsible for the reduction of nitrate to nitrite. The produced nitrite acts as an SRB inhibition agent. It is also an effective $\mathrm{H}_{2} \mathrm{~S}$ scavenger as it reacts with sulfide resulting in the generation of elemental sulfur and nitrogen (Sturman and Goeres 1999). Microbial competition between NRB and SRB for electron donors (oil-derived organics or $\mathrm{H}_{2}$ ) and nitrate-driven sulfide oxidation are the two mechanisms proposed for the NRB-facilitated souring control (Sunde et al. 2004; Dolfing and Hubert 2017). There are concerns that nitrate treatment shifts the corrosion risk from production to injection wells due to the oxidizing potentials of nitrate and nitrite (Martin 2008; Hubert et al. 2005). Depending on the ratio of nitrate to sulfide, fully oxidized sulfate or partially oxidized sulfur-polysulfides may be generated; sulfide is oxidized to sulfate at high nitrate to sulfide ratios with the reduction of nitrate to nitrite, while, at low ratios, sulfur-polysulfide formation is favored (Sturman and Goeres 1999). The latter conditions can be encountered at oilfield topside at low temperatures $\left(4-85^{\circ} \mathrm{C}\right.$ ) (Dolfing and Hubert 2017). These intermediate sulfur species could also be formed rapidly by chemical reactions, when soured produced water containing substantial sulfide concentrations is exposed to air (Johnston et al. 2010). The oxidation of sulfide to sulfate is a kinetically slow reaction that requires a biological catalyst to occur at a significant rate. Therefore, partially oxidation of sulfide to elemental sulfur and other intermediate sulfur species is a more probable reaction pathway. The formed intermediate sulfur compounds may cause corrosion. The corrosive nature of these compounds has been well documented (Dowling 1992; Alekseev et al. 1990; Fang et al. 2011). Polysulfide, for example, acts as an oxidizer that receives electrons from steel surfaces to form sulfide (Ramo and Sillanpaa 2003). Sulfur can react rapidly with metallic iron to form iron sulfide and other iron sulfur compounds such as greigite $\left(\mathrm{Fe}_{3} \mathrm{~S}_{4}\right)$ and pyrite $\left(\mathrm{FeS}_{2}\right)$ (Johnston et al. 2010; Dronen et al. 2014). The formed iron sulfide is essentially insoluble in aqueous solution leading to high local corrosion rates. Partially oxidized sulfur species can acidify natural waters (O'Reilly et al. 2001). Theses reduced forms of sulfur entering the environment can also influence the bioavailability of heavy metals due to complexation and precipitation (Witter and Jones 1998).

These findings have implications for reservoir souring management strategies (Nemati et al. 2001). For example, under conditions encountered in oilfields, where there is an abundance of electron donors, sulfate reduction to sulfide is more favorable than sulfide oxidation to elemental sulfur. Sulfide oxidation to intermediate sulfur species is, on the other hand, most problematic in oil/water topside separation tanks where nitrate levels are low. The occurrence and behaviour of these intermediate sulfur species and their impact on souring/scaling process need to be investigated for developing souring control strategies. This could be achieved through identifying the possible compounds involved and studying the thermodynamic and reaction rate data with respect to these species present.

\section{Sulfur chemistry and reservoir souring}

Intermediate sulfur species in produced fluids indicate that there are microbial and chemical reactions occurring as the reservoir fluids flow from injection to production wells. The reactivity of these compounds is complex and depends upon temperature, $\mathrm{pH}$, as well as the presence of other sulfur species, metals, and microorganisms. The possible origins of these compounds have been studied under different temperature and $\mathrm{pH}$ conditions (Takano et al. 1994; Zhang and Millero 1993; Chen and Morris 1972; Xu et al. 2000; Gieg et al. 2011; Orphan et al. 2000; Tang et al. 2009; Muyzer and Stams 2008; Barrett and Clark 1987; Moura et al. 1997; Dalsgaard and Bak 1994). The incomplete redox reactions involving $\mathrm{H}_{2} \mathrm{~S}$, sulfur dioxide, or sulfate are likely causes of the generation of sulfur oxyanions. Partial reoxidation of $\mathrm{H}_{2} \mathrm{~S}$ to sulfur may occur in low-temperature aerobic environments, where molecular oxygen presents, and in hightemperature anaerobic environments, excess sulfate acts as the oxidant. Intermediate sulfur species can also be reduced to sulfide due to the SRB activity. Some sulfate reducers can reduce sulfur compounds such as thiosalts, sulfite, and 
sulfur (Muyzer and Stams 2008; Barrett and Clark 1987; Moura et al. 1997; Dalsgaard and Bak 1994). Thermophilic sulfur reducers and thiosulfate reducers have been isolated from produced water at temperatures ranging from 60 to $90{ }^{\circ} \mathrm{C}$ (Gieg et al. 2011; Orphan et al. 2000). A mesophilic SRB has been detected in oil fields at temperature of $30{ }^{\circ} \mathrm{C}$ and $\mathrm{pH} 7$, and reduced sulfate, sulfite, and thiosulfate in the presence of lactate (Gieg et al. 2011).

\section{Thiosalts}

Thiosalts are important intermediate sulfur species which are undesirable in the environment as they can acidify natural waters (Witter and Jones 1998; Druschel et al. 2003; O'Reilly et al. 2001; Wang et al. 2013; Miranda-Trevino et al. 2013; Millero 1986; Kuyucak and Yaschyshyn 2007). Their reactivity is dependent upon temperature, $\mathrm{pH}$, and the presence of oxygen and other thiosalts, metals, and microorganisms (Miranda-Trevino et al. 2013). Strong oxidants and biological and/or chemical catalysts such as iron catalyze the chemical breakdown of polythionates to thiosulfate and sulfite (Schippers and Sand 1999). Thiosalts formed in the reservoir could rapidly react to form $\mathrm{H}_{2} \mathrm{~S}$ or other sulfur species on the topsides (i.e., in produced water systems). Thiosalts can also be produced from the oxidation of pyrite. The two common oxidants are ferric ion and oxygen. The former is the main oxidant at low $\mathrm{pH}$ values, and the latter is more important at neutral pH (Schippers et al. 1996; Schippers and Sand 1999):

$\mathrm{FeS}_{2}+6 \mathrm{Fe}^{3+}+3 \mathrm{H}_{2} \mathrm{O} \rightarrow 7 \mathrm{Fe}^{2+}+6 \mathrm{H}^{+}+\mathrm{S}_{2} \mathrm{O}_{3}{ }^{2-}$

$\mathrm{FeS}_{2}+7 / 2 \mathrm{O}_{2}+\mathrm{H}_{2} \mathrm{O} \rightarrow \mathrm{Fe}^{2+}+2 \mathrm{H}^{+}+2 \mathrm{SO}_{4}{ }^{2-}$.

In acidic aqueous solutions at temperatures between 4 and $30{ }^{\circ} \mathrm{C}$, thiosulfate is further oxidized to tetrathionate as follows (Miranda-Trevino et al. 2013; Takano et al. 1994; Zhang and Millero 1993; Chen and Morris 1972; Xu et al. 2000):

$$
\begin{aligned}
& 2 \mathrm{~S}_{2} \mathrm{O}_{3}^{2-}+2 \mathrm{H}^{+}+1 / 2 \mathrm{O}_{2} \rightarrow \mathrm{S}_{4} \mathrm{O}_{6}^{2-}+\mathrm{H}_{2} \mathrm{O} \\
& 2 \mathrm{~S}_{2} \mathrm{O}_{3}^{2-}+2 \mathrm{Fe}^{3+} \rightarrow \mathrm{S}_{4} \mathrm{O}_{6}^{2-}+2 \mathrm{Fe}^{2+} .
\end{aligned}
$$

Pyrite has been shown to act as a catalyst in the tetrathionate formation reaction in both acidic and basic conditions (Xu and Schoonen 1995):

$3 \mathrm{~S}_{2} \mathrm{O}_{3}^{2-}+\mathrm{FeS}_{2} \rightarrow \mathrm{S}_{4} \mathrm{O}_{6}^{2-}+\mathrm{FeS}+\mathrm{H}_{2} \mathrm{~S}$.

Tetrathionate is stable in acid solutions, and degrades to thiosulfate and sulfite at neutral $\mathrm{pH}$. At low $\mathrm{pH}$ values, however, tetrathionate is decomposed to sulfate if the ferric ion presents:

$4 \mathrm{~S}_{4} \mathrm{O}_{6}^{2-}+3 \mathrm{Fe}^{3+}+2.75 \mathrm{O}_{2}+4.5 \mathrm{H}_{2} \mathrm{O} \rightarrow 4 \mathrm{SO}_{4}^{2-}+3 \mathrm{Fe}^{2+}+9 \mathrm{H}^{+}$.
In the presence of a strong alkaline media, trithionate is a probable intermediate of tetrathionate reduction (Xu and Schoonen 1995):

$$
\begin{gathered}
4 \mathrm{~S}_{4} \mathrm{O}_{6}^{2-}+6 \mathrm{OH}^{-} \rightarrow 5 \mathrm{~S}_{2} \mathrm{O}_{3}^{2-}+2 \mathrm{~S}_{3} \mathrm{O}_{6}^{2-}+3 \mathrm{H}_{2} \mathrm{O} \\
\mathrm{pH}=9, \quad T=4-30^{\circ} \mathrm{C} .
\end{gathered}
$$

At pH 3.5-4 and temperatures between 20 and $70{ }^{\circ} \mathrm{C}$, trithionate and pentathionate are formed from tetrathionate decomposition through a second-order reaction (MirandaTrevino 2013; Zhang and Jeffrey 2010):

$2 \mathrm{~S}_{4} \mathrm{O}_{6}^{2-} \rightarrow \mathrm{S}_{5} \mathrm{O}_{6}^{2-}+\mathrm{S}_{3} \mathrm{O}_{6}^{2-}$.

Trithionate is stable in neutral and acidic conditions and its reactivity increases with $\mathrm{pH}$ (Miranda-Trevino et al. 2013):

$$
\begin{aligned}
3 \mathrm{~S}_{3} \mathrm{O}_{6}^{2-} & \rightarrow \mathrm{S}_{4} \mathrm{O}_{6}{ }^{2-}+1 / 8 \mathrm{~S}_{8}+2 \mathrm{SO}_{4}{ }^{2-}+2 \mathrm{SO}_{2} \\
\mathrm{pH} & =4, \quad T=5^{\circ} \mathrm{C} .
\end{aligned}
$$

At high temperatures, between 70 and $150{ }^{\circ} \mathrm{C}$, the proposed reaction for degradation of trithionate is as follows:

$$
\begin{gathered}
\mathrm{S}_{3} \mathrm{O}_{6}^{2-}+\mathrm{H}_{2} \mathrm{O} \rightarrow \mathrm{S}_{2} \mathrm{O}_{3}^{2-}+\mathrm{SO}_{4}^{2-}+2 \mathrm{H}^{+} \\
\mathrm{pH}=2-4, \quad T=70-150^{\circ} \mathrm{C} .
\end{gathered}
$$

The presence of ferric ion promotes the oxidation of trithionate at $\mathrm{pH}$ near to neutral (Wang et al. 2013; Zhang et al. 2011).

$$
\begin{gathered}
\mathrm{S}_{3} \mathrm{O}_{6}^{2-}+2 \mathrm{Fe}^{3+}+1 / 2 \mathrm{O}_{2} \rightarrow \mathrm{S}_{2} \mathrm{O}_{3}^{2-}+\mathrm{SO}_{4}^{2-}+4 \mathrm{Fe}^{2+} \\
\mathrm{pH}=7-9, \quad T=30^{\circ} \mathrm{C} .
\end{gathered}
$$

The oxidation of trithionate at $\mathrm{pH}$ below 7 and in highly basic solutions ( $\mathrm{pH}$ around 12) follows the same reaction. However, in acidic conditions, the produced thiosulfate is further oxidized to tetrathionate and sulfite. At $\mathrm{pH}$ between 3.5 and 4 and temperatures between 20 and $70{ }^{\circ} \mathrm{C}$, trithionate is first decomposed to tetrathionate and sulfate and then to sulfur dioxide and sulfur:

$\mathrm{S}_{3} \mathrm{O}_{6}^{2-}+2 \mathrm{OH}^{-} \rightarrow \mathrm{S}_{2} \mathrm{O}_{3}^{2-}+\mathrm{SO}_{4}^{2-}+2 \mathrm{H}_{2} \mathrm{O}$.

\section{Hydrogen sulfide and polysulfide ions}

Hydrogen sulfide is a weak acid in water and depending on the $\mathrm{pH}$ of the environment, it may exist as bisulfide or sulfide ions. In low-temperature diagenetic settings $\left(T<100{ }^{\circ} \mathrm{C}\right)$, where oxygen is available and $\mathrm{pH}$ conditions are favorable, sulfide can be oxidized to elemental sulfur. Several models have been developed to predict the partitioning behaviour of $\mathrm{H}_{2} \mathrm{~S}$ in reservoir fluids and to investigate the effects of temperature, pressure, fluids composition, ionic strength, 
and water $\mathrm{pH}$ on the $\mathrm{H}_{2} \mathrm{~S}$ mass production rate (Eden et al. 1993; Burger et al. 2005; Schofield and Stott 2012; Ligthelm et al. 2000; King and Al-Najjar 1977; Sunde et al. 1993; Tyrie and Ljosland 1993). The dissolution of $\mathrm{H}_{2} \mathrm{~S}$ in water involves a series of chemical reactions: the dissociation of the molecular $\mathrm{H}_{2} \mathrm{~S}$ to bisulfide and sulfide ions and the selfionization of water (Burger et al. 2013):

$\mathrm{H}_{2} \mathrm{~S}_{(\mathrm{aq})} \stackrel{\mathrm{k}_{1}}{\longleftrightarrow} \mathrm{HS}^{-}+\mathrm{H}^{+}$

$\mathrm{HS}^{-} \stackrel{\mathrm{k}_{2}}{\longleftrightarrow} \mathrm{S}^{2-}+\mathrm{H}^{+}$

$\mathrm{H}_{2} \mathrm{O} \stackrel{\mathrm{k}_{3}}{\longleftrightarrow} \mathrm{OH}^{-}+\mathrm{H}^{+}$.

The equilibrium constants for the above reactions are obtained over a wide range of temperature (Burger et al. 2013). The solubility of $\mathrm{H}_{2} \mathrm{~S}$ in a salt solution decreases as the ionic salt concentrations increase. This phenomenon, called the salting-out effect, may be characterized by Setschenow and formulated in terms of the ratio of solubilities in pure water and in an aqueous salt solution at a constant temperature (Burger et al. 2013).

Rate constants for the oxidation of sulfide in seawater and formation of sulfite, sulfate, and thiosulfate were determined as a function of $\mathrm{pH}$, temperature, and salinity. The reactions are overall second-order reactions, first-order with respect to both sulfide and oxygen (Zhang and Millero 1993):

$\mathrm{H}_{2} \mathrm{~S}+1.5 \mathrm{O}_{2} \stackrel{\mathrm{k}_{1}}{\longrightarrow} \mathrm{SO}_{3}^{2-}+2 \mathrm{H}^{+}$

$\mathrm{SO}_{3}^{2-}+0.5 \mathrm{O}_{2}+\mathrm{H}_{2} \stackrel{\mathrm{k}_{2}}{\longrightarrow} \mathrm{SO}_{4}^{2-}+2 \mathrm{H}^{+}$

$\mathrm{H}_{2} \mathrm{~S}+\mathrm{SO}_{3}^{2-}+0.5 \mathrm{O}_{2} \stackrel{\mathrm{k}_{3}}{\longrightarrow} \mathrm{S}_{2} \mathrm{O}_{3}^{2-}+\mathrm{H}_{2} \mathrm{O}$.

It is believed that the dissolution of elemental sulfur in aqueous sulfide solutions is the precursor for the formation of polysulfide anions (Petre and Larachi 2006):

$\mathrm{S}_{n}+\mathrm{HS}^{-}+\mathrm{OH}^{-} \Leftrightarrow \mathrm{S}_{n+1}{ }^{2-}+\mathrm{H}_{2} \mathrm{O}$.

The distribution of the resulting anions reaches equilibrium rapidly which leads to the formation of different chain lengths:

$(n-1) \mathrm{S}_{n+1}{ }^{2-}+\mathrm{HS}^{-}+\mathrm{OH}^{-} \Leftrightarrow n \mathrm{~S}_{n}{ }^{2-}+\mathrm{H}_{2} O \quad n=2-5$.

In aqueous solutions, the autooxidation of the polysulfide anions also occurs rapidly which results in thiosulfate formation:

$\mathrm{S}_{n}{ }^{2-}+3 / 2 \mathrm{O}_{2} \rightarrow \mathrm{S}_{2} \mathrm{O}_{3}{ }^{2-}+[(n-2) / 8] \mathrm{S}_{8}$.
If the formation of thiosulfate is not suppressed, it can be oxidized to polythionates. Under alkaline conditions, hydrogen sulfide reacts with polythionates and forms polysulfides (Steudel 1996). Polysulfides are relatively unstable and are easily decomposed to elemental sulfur when exposed to water. The solubility of sulfur in the solution is mainly controlled by temperature and pressure and it has been shown that high bottom hole temperatures and low wellhead pressures provide favorable conditions for sulfur deposition which blocks the pores in the formation (Shedid and Zekri 2002; Adesina et al. 2012). The influences of operational and reservoir parameters on elemental sulfur plugging in oil and gas reservoirs have been studied by several investigators (Shedid and Zekri 2002; Abou-Kassem 2000; Chernik and Williams 1993; Roberts 1997). A decrease in temperature and pressure also leads to the decomposition of polysulfides (Bojes et al. 2010). Polysulfides are also known to play a key role in the formation of volatile sulfur compounds in natural aquatic systems (Petre and Larachi 2006). Polysulfide ions can react with $\mathrm{H}^{+}$to form hydrogen polysulfides which, near or below $\mathrm{pH} 7$, lead to the formation of homocyclic molecule $S_{8}$. The formed elemental sulfur can precipitate as a solid and cause plugging in the reservoir, well-bore, or surface facilities (Millero 1986):

$\mathrm{S}_{n}{ }^{2-}+\mathrm{H}^{+} \Leftrightarrow \mathrm{HS}_{n}{ }^{-} \Leftrightarrow \mathrm{HS}^{-}+[(n-1) / 8] \mathrm{S}_{8}$.

Hydrogen polysulfides have relatively strong acidities in the gas phase which correlate with the chain length. Hydrogen polysulfides can react with basic species such as bicarbonate ions in the formation water and produce water-soluble ionic polysulfides as follows:

$\mathrm{H}_{2} \mathrm{~S}_{n}+\mathrm{HCO}_{3}{ }^{-} \Leftrightarrow \mathrm{HS}_{n}{ }^{-}+\mathrm{H}_{2} \mathrm{O}+\mathrm{CO}_{2(g)}$.

Sulfur can also be oxidized to other sulfur oxyanions such as sulfate, sulfite, polysulfides, and thiosulfate. As $\mathrm{pH}$ of the solution increases through neutral conditions, the rate of oxidation of sulfide increases, whereas it decreases in more alkaline solutions (Wang et al. 2013; Machel 1992):

$n \mathrm{HS}^{-}+(n-1) / 2 \mathrm{O}_{2} \Leftrightarrow \mathrm{S}_{n}{ }^{2-}+\mathrm{H}_{2} O+(n-2) \mathrm{OH}^{-}$

$\mathrm{S}_{n}{ }^{2-}+3 / 2 \mathrm{O}_{2} \Leftrightarrow \mathrm{S}_{2} \mathrm{O}_{3}{ }^{2-}+(n-2) / 8 \mathrm{~S}_{8}$

$\mathrm{S}_{n}{ }^{2-}+3 / 2 \mathrm{O}_{2} \Leftrightarrow \mathrm{SO}_{3}{ }^{2-}+(n-1) / 8 \mathrm{~S}_{8}$

$\mathrm{SO}_{3}{ }^{2-}+1 / 2 \mathrm{O}_{2} \Leftrightarrow \mathrm{SO}_{4}{ }^{2-}$.

In the presence of a transition metal, like ferric ion, the overall process of sulfide oxidation may be represented as follows:

$\mathrm{HS}^{-}+2 \mathrm{M}^{n+} \rightarrow \mathrm{S}^{0}+\mathrm{H}^{+}+2 \mathrm{M}^{(n-1)+}$.

Table 1 summarizes the published reaction rates reported for different sulfur species under acidic and basic conditions.

As indicated above, thiosalts are active intermediates in bacterial reactions but not discussed in detail here. However, 
it is clear from the discussion above that the type of sulfur compound can vary significantly within the reservoir and topsides processing facilities depending on the temperature, pressure, and $\mathrm{pH}$. These same compounds can act as growth promoters or inhibitors of bacterial growth and corrosion. Therefore, a more complete understanding of how sulfur partitions and chemically reacts is required to better manage reservoir souring and topsides damage/safety concerns.

\section{Detection and quantification of reduced sulfur compounds}

Sulfur and sulfur-oxygen species are highly reactive, and speciation, decomposition, and oxidation of these compounds will occur. This makes the chemistry of such solutions quite complex and, therefore, difficult to accurately analyze (Moses et al. 1984; Takano and Watanuki 1998;
Safizadeh and Larachi 2014). Chemical techniques such as titration, gravimetric analysis, and colorimetric techniques have been used for the analysis of thiosalts including, thiosulfate, trithionate, tetrathionate, and pentathionate either individually or in a mixture (Miranda-Trevino et al. 2013; O'Reilly et al. 2001). Thiosulfate can be determined by titrimetric methods where iodine or iodate is usually used as the titrant (Ciesielski et al. 2001) and in mixtures with other sulfur species such as sulfide and sulfite using formaldehyde to mask sulfite (Harris 2010). Total thiosalts have been determined by acidimetric titration carried out at the methyl orange or at the phenolphthalein end-point (Makhija and Hitchen 1978). The method has been described to distinguish between non-oxidizable sulfate and the oxidizable thiosalts. Samples containing as low as $0.1 \mathrm{mg}$ of thiosalts can be analyzed easily and accurately.

Traditionally, total sulfide species or hydrogen sulfide in natural waters has been measured by colorimetric methods

Table 1 Summary of sulfur reactions from the literature under both acidic and basic conditions

\begin{tabular}{|c|c|c|c|c|}
\hline \multicolumn{2}{|l|}{ Reaction } & \multirow{2}{*}{$\frac{\mathrm{pH}}{5-8}$} & \multirow{2}{*}{$\frac{T\left({ }^{\circ} \mathrm{C}\right)}{-}$} & \multirow{2}{*}{$\frac{\text { References }}{\text { Morse et al. (1987) }}$} \\
\hline Polysulfides & $\mathrm{H}_{2} \mathrm{~S} \leftrightarrow \mathrm{H}^{+}+\mathrm{HS}^{-}$ & & & \\
\hline & $\mathrm{HS}^{-} \leftrightarrow \mathrm{H}^{+}+\mathrm{S}^{2-}$ & $>7$ & - & Morse et al. (1987) \\
\hline & $\mathrm{H}_{2} \mathrm{~S}+\mathrm{SO}_{3}^{2-}+0.5 \mathrm{O}_{2} \rightarrow \mathrm{S}_{2} \mathrm{O}_{3}^{2-}+\mathrm{H}_{2} \mathrm{O}$ & $4-10$ & - & Zhang and Millero (1991) \\
\hline & $\mathrm{HS}^{-}+2 \mathrm{Fe}^{3+} \rightarrow 1 / 8 \mathrm{~S}_{8}+\mathrm{H}^{+}+2 \mathrm{Fe}^{2+}$ & $5-8$ & - & Wilkin and Barnes (1996) \\
\hline & $n \mathrm{~S}^{2-}+2(n-1) \mathrm{H}_{2} \mathrm{O} \rightarrow \mathrm{S}_{n}^{2-}+2(n-1) \mathrm{OH}^{-}+(n-1) \mathrm{H}_{2}$ & $>7$ & $>70$ & Schippers and Sand (1999) \\
\hline & $n \mathrm{HS}^{-}+(n-1) / 2 \mathrm{O}_{2} \rightarrow \mathrm{S}_{n}{ }^{2-}+\mathrm{H}_{2} \mathrm{O}+(n-2) \mathrm{OH}^{-}$ & - & - & Zopfi et al. (2004) \\
\hline & $\mathrm{S}_{n}{ }^{2-}+3 / 2 \mathrm{O}_{2} \rightarrow \mathrm{S}_{2} \mathrm{O}_{3}^{2-}+[(n-2) / 8] \mathrm{S}_{8}$ & - & - & Petre and Larachi (2006) \\
\hline & $\mathrm{HS}^{-}+\mathrm{SO}_{3}^{2-}+0.5 \mathrm{O}_{2} \rightarrow \mathrm{S}_{2} \mathrm{O}_{3}^{2-}+\mathrm{OH}^{-}$ & $5-8$ & - & Zopfi et al. (2004) \\
\hline & $\mathrm{H}_{2} \mathrm{~S}+1.5 \mathrm{O}_{2} \rightarrow \mathrm{SO}_{3}^{2-}+2 \mathrm{H}^{+}$ & $4-10$ & - & Zhang and Millero (1993) \\
\hline & $\mathrm{SO}_{3}^{2-}+0.5 \mathrm{O}_{2}+\mathrm{H}_{2} \rightarrow \mathrm{SO}_{4}^{2-}+2 \mathrm{H}^{+}$ & $4-10$ & - & Zhang and Millero (1993) \\
\hline \multirow[t]{18}{*}{ Thiosalts } & $\mathrm{S}_{2} \mathrm{O}_{3}^{2-}+\mathrm{H}_{2} \mathrm{O} \rightarrow \mathrm{H}_{2} \mathrm{~S}+\mathrm{SO}_{4}^{2-}$ & 12 & $>70$ & Moses et al. (1987) \\
\hline & $\mathrm{S}_{2} \mathrm{O}_{3}^{2-}+2 \mathrm{O}_{2}+\mathrm{H}_{2} \mathrm{O} \rightarrow 2 \mathrm{SO}_{4}^{2-}+2 \mathrm{H}^{+}$ & $>7$ & 25 & Miranda-Trevino (2013) \\
\hline & $\mathrm{S}_{3} \mathrm{O}_{6}^{2-}+\mathrm{Fe}^{3+}+1 / 2 \mathrm{O}_{2} \rightarrow \mathrm{S}_{2} \mathrm{O}_{3}^{2-}+\mathrm{SO}_{4}^{2-}+\mathrm{Fe}^{2+}$ & $7-9$ & 30 & Miranda-Trevino et al. (2013) \\
\hline & $2 \mathrm{~S}_{4} \mathrm{O}_{6}^{2-} \rightarrow \mathrm{S}_{5} \mathrm{O}_{6}^{2-}+\mathrm{S}_{3} \mathrm{O}_{6}^{2-}$ & 9 & $4-30$ & Miranda-Trevino et al. (2013) \\
\hline & $\mathrm{S}_{3} \mathrm{O}_{6}^{2-}+2 \mathrm{OH}^{-} \rightarrow \mathrm{S}_{2} \mathrm{O}_{3}^{2-}+\mathrm{SO}_{4}^{2-}+2 \mathrm{H}_{2} \mathrm{O}$ & $>7$ & - & Druschel et al. (2003) \\
\hline & $4 \mathrm{~S}_{4} \mathrm{O}_{6}^{2-}+6 \mathrm{OH}^{-} \rightarrow 5 \mathrm{~S}_{2} \mathrm{O}_{3}^{2-}+2 \mathrm{~S}_{3} \mathrm{O}_{6}^{2-}+3 \mathrm{H}_{2} \mathrm{O}$ & $>7$ & - & Druschel et al. (2003a) \\
\hline & $2 \mathrm{~S}_{4} \mathrm{O}_{6}^{2-}+6 \mathrm{OH}^{-} \rightarrow 3 \mathrm{~S}_{2} \mathrm{O}_{3}^{2-}+2 \mathrm{SO}_{3}^{2-}+3 \mathrm{H}_{2} \mathrm{O}$ & $>7$ & - & Druschel et al. (2003a) \\
\hline & $4 \mathrm{~S}_{4} \mathrm{O}_{6}^{2-}+4 \mathrm{H}_{2} \mathrm{O} \rightarrow 6 \mathrm{~S}_{2} \mathrm{O}_{3}{ }^{2-}+\mathrm{S}_{3} \mathrm{O}_{6}{ }^{2-}+\mathrm{SO}_{4}{ }^{2-}+8 \mathrm{H}^{+}$ & $<7$ & $25-70$ & Zhang and Jeffrey (2010) \\
\hline & $\mathrm{S}_{2} \mathrm{O}_{3}^{2-}+\mathrm{O}_{2} \rightarrow \mathrm{S}_{4} \mathrm{O}_{6}^{2-}+\mathrm{SO}_{3}^{2-}$ & $<7$ & 25 & Druschel et al. (2003) \\
\hline & $3 \mathrm{~S}_{3} \mathrm{O}_{6}^{2-} \rightarrow \mathrm{S}_{4} \mathrm{O}_{6}^{2-}+1 / 8 \mathrm{~S}_{8}+2 \mathrm{SO}_{4}{ }^{2-}+2 \mathrm{SO}_{2}$ & 4 & 35 & Zhang and Jeffrey (2010) \\
\hline & $2 \mathrm{~S}_{2} \mathrm{O}_{3}{ }^{2-}+2 \mathrm{Fe}^{3+} \rightarrow \mathrm{S}_{4} \mathrm{O}_{6}{ }^{2-}+2 \mathrm{Fe}^{2+}$ & $2.9-6.6$ & $25-70$ & Xu and Schoonen (1995) \\
\hline & $\mathrm{S}_{3} \mathrm{O}_{6}^{2-}+\mathrm{H}_{2} \mathrm{O} \rightarrow \mathrm{S}_{2} \mathrm{O}_{3}^{2-}+\mathrm{SO}_{4}^{2-}+2 \mathrm{H}^{+}$ & $2-4$ & $70-150$ & Miranda-Trevino et al. (2013) \\
\hline & $2 \mathrm{~S}_{2} \mathrm{O}_{3}{ }^{2-}+2 \mathrm{H}^{+}+0.5 \mathrm{O}_{2} \rightarrow \mathrm{S}_{4} \mathrm{O}_{6}^{2-}+\mathrm{H}_{2} \mathrm{O}$ & 2.9 & $25-70$ & Miranda-Trevino et al. (2013) \\
\hline & $4 \mathrm{~S}_{4} \mathrm{O}_{6}^{2-}+3 \mathrm{Fe}^{3+}+2.75 \mathrm{O}_{2}+4.5 \mathrm{H}_{2} \mathrm{O} \rightarrow 4 \mathrm{SO}_{4}^{2-}+3 \mathrm{Fe}^{2+}+9 \mathrm{H}^{+}$ & 4 & 70 & Druschel et al. (2003) \\
\hline & $2 \mathrm{~S}_{4} \mathrm{O}_{6}^{2-} \rightarrow \mathrm{S}_{5} \mathrm{O}_{6}^{2-}+\mathrm{S}_{3} \mathrm{O}_{6}^{2-}$ & 9 & $4-30$ & Miranda-Trevino et al. (2013) \\
\hline & $2 \mathrm{~S}_{2} \mathrm{O}_{3}^{2-}+\mathrm{H}^{+} \rightarrow \mathrm{HSO}_{3}^{-}+\mathrm{SO}_{3}^{2-}+2 \mathrm{~S}^{0}$ & 2.9 & 25 & Zopfi et al. (2004) \\
\hline & $5 \mathrm{~S}_{2} \mathrm{O}_{3}^{2-}+6 \mathrm{H}^{+} \rightarrow 2 \mathrm{~S}_{4} \mathrm{O}_{6}^{2-}+2 \mathrm{~S}^{0}+3 \mathrm{H}_{2} \mathrm{O}$ & $<7$ & $70-150$ & Barrett and Clark (1987) \\
\hline & $\mathrm{S}_{3} \mathrm{O}_{6}^{2-}+\mathrm{H}_{2} \mathrm{O} \rightarrow \mathrm{S}_{2} \mathrm{O}_{3}^{2-}+\mathrm{SO}_{4}^{2-}+2 \mathrm{H}^{+}$ & $2-4$ & $70-110$ & Xu et al. (2000) \\
\hline
\end{tabular}


with methylene blue (Sakamoto-Arnold et al. 1986; Lawrence et al. 2000). Various electrochemical methods based on different pulse voltammetry of silver or mercury electrodes, amperometric detectors, as well as potentiometry have been widely used to measure dissolved sulfide in aqueous media (Sakamoto-Arnold et al. 1986; Green and Blough 1994; Jeroschewski et al. 1996; Jorgensen 1990; Ciglenečki et al. 2014). Cyclic voltammetry or linear sweep voltammetry was used for separating free polysulfides, elemental sulfur, and bisulfide with fast scan rates (Rozan et al. 2000).

These chemical methods are time-consuming. Electrochemical methods such as polarography and voltammetry can determine two or three species in a single scan faster than wet chemistry methods. To directly determine total ionic polysulfides in the presence of other sulfur species (e.g., polythionates and sulfide), differential pulse polarography in combination with a dropping mercury electrode was used (Kariuki et al. 2001). Due to the specificity of the technique and the lack of interferences, the method is attractive for the measurements of samples with polysulfide concentrations between $10^{-5}$ and $10^{-3} \mathrm{M}$.

Spectrophotometry methods have been applied to determine total polythionates, thiosulfate, and sulfite mixed in various ratios (Koh 1990). The method has also been used for polythionates and sulfide mixtures (Miura et al. 1998). Tetrathionate has also been measured by mixing with iodate to form sulfate and iodide and the formed iodide was measured as triiodide via spectrophotometry (Miura et al. 1991). The spectrophotometric methods cannot simultaneously measure all the thiosalt species due to requirement of masking and conversion of one form of the compound to another (Miura et al. 1998).

Thiosalt species have also been analyzed using spectroscopic analyses such as infra-red (IR) and ultraviolet (UV) (Bandekar et al. 1995; Rozan et al. 2000). The detection limits of these methods are typically in the range $10^{-4}$ to $10^{-2} \mathrm{M}$ which are higher than those of other instruments. Thiosalts have relatively strong UV absorbance and, therefore, more selective direct detection at $214 \mathrm{~nm}$ is used (Padarauskas et al. 2000). Thiosulfate, trithionate, tetrathionate, and pentathionate have been detected using indirect UV-Vis detection (Pappoe and Bottaro 2014). Fully ionized pyromellitate ion (PMA) with a high molar absorptivity was used as the chromophoric probe. The method was rapid, sensitive, and selective with limits of detection between 0.02 and $0.12 \mu \mathrm{g} /$ $\mathrm{ml}$. Total dissolved sulfide in natural waters has also been determined using direct ultraviolet detection of bisulfide ion (Guenther et al. 2001).

Montes-Rosua et al. (2016) proposed an indirect method based on conductivity measurement for determining polythionate concentrations in a sample process water. However, different types of polythionates cannot be discriminated by this method.
A liquid chromatographic separation and polarographic method was developed by Takano and Watanuki (1998) to separate and analyze a mixture of polythionates. Different high-performance liquid chromatography (HPLC) techniques have been used for the separation of polythionates (Chapman and Beard 1973; Takano and Watanuki 1998; Tang and Santschi 2000). The selectivity of these methods is low, especially when samples with complicated matrices are analyzed.

Since the conventional methods are quite time-consuming and difficult to employ in the analysis of sulfur species in very complex matrices, modern techniques based on ion chromatography (IC) and capillary electrophoresis (CE) have been applied with detection sensitivity in the range $10^{-7}$ to $10^{-5} \mathrm{M}$ (Jeffrey and Brunt 2007; Miura and Watanabe 2001). Sulfate, sulfite, thiosulfate, and sulfide have been determined by IC methods in sulfur speciation studies (e.g., O'Reilly et al. 2001). Moses et al. (1984) determined polythionates indirectly through the determination of thiocyanate. In classical ion-exchange chromatography methods, thiosulfate has been used as an eluent to separate metal ions through the formation of metal-thiosulfate complexes. These classical methods were not able to separate more than five complexes in one analysis. Polythionate separations are easier to achieve using modern anion-exchange and ioninteraction chromatographic methods. The sensitivity of UV detection for trithionate quantification is low and an anionexchange column is an alternative approach to ion-pair chromatography (Jeffrey and Brunt 2007). Ion chromatography and electrochemical detection with a glassy carbon electrode chemically modified with palladium particles have shown the ability to catalyze sulfide oxidation over wide potential and $\mathrm{pH}$ ranges and, therefore, could detect dissolved ions in aqueous solutions (Casella et al. 2000). Sulfate, thiosulfate, and polythionates have been analyzed using IC in hydrothermal waters, while total dissolved sulfide is measured by titration and colorimetry (Kaasalainen and Stefansson 2011).

$\mathrm{CE}$ can be used for separation, detection, and quantification of thiosalt species (Buchberger and Haddad 1992; Corr and Anacleto 1996; Daunoravicius and Padarauskas 2002; Haddad et al. 1999; Padarauskas et al. 2000; Motellier and Descostes 2001; O'Reilly et al. 2003; Saeed 2017). CE is a technique for separation of ions based on their size to charge ratio and an attractive alternative to the traditional methods due to its high separation efficiency, low running costs, tolerances for sample matrices with high ionic strength, and the generation of a low amount of waste (O'Reilly et al. 2001). $\mathrm{CE}$ is also a rapid method and minimizes sulfur speciation during separation, making it suitable for the analysis of unstable sulfur-containing species. Separation of sulfide, thiosulfate, sulfite, and sulfate has been generally achieved with co-electric-osmotic flow (EOF) through the addition of an EOF modifier to the background electrolyte (BGE). In 
this separation mode, sulfide migrates faster than the other ions and thiosulfate has the slowest migration rate. However, increasing the EOF modifier in the BGE reduces sulfide mobility due to the formation of ion-pairs between sulfide and EOF modifier and can change the separation selectivity (Petre and Larachi 2006). Using the anodic oxidation procedure, thiosulfate is completely converted to sulfate, and for this reason, the change in sulfate concentration should also be monitored. Sulfate, however, has no UV absorbance. Indirect UV detection in CE is, therefore, used to detect nonabsorbing ions. Due to high UV absorbance, polythionates cannot be detected with indirect CE method and only were sulfate, sulfite, and thiosulfate detected (Padarauskas et al. 2000). In addition, there is a challenge in separating chloride from thiosulfate in saline water samples, implying the necessity of using direct CE method (Saeed 2017).

Other separation techniques for sulfur speciation include planar chromatographic, ion-exclusion chromatography, reversed-phase liquid chromatography, gas chromatography, and capillary electrochromatography. A review of these methods can be found in O'Reilly et al. (2001). Table 2 summarizes the analytical techniques used in sulfur speciation studies.

\section{Conclusions}

The presence of sulfur species in produced oil and gas results in operational, environmental, and treatment problems. Combination of sulfur species including sulfite, polysulfides, polythionates, and thiosulfate has been detected in some produced water samples along with hydrogen sulfide, likely a result of phase partitioning, and chemical and microbial reactions. These intermediate sulfur species have implications in both biology and geology and could impact the treatment approaches for sour reservoirs. Not only do these sulfur compounds impact the amount of $\mathrm{H}_{2} \mathrm{~S}$ in the various phases, but also they affect the overall reactivity of the produced fluids in terms of sulfur. The incomplete redox reactions involving $\mathrm{H}_{2} \mathrm{~S}$, sulfur dioxide, or sulfate are likely causes of the generation of sulfur oxyanions. Understanding the sulfur chemistry is important to define the gaps in the souring reactions and phase behaviour occurring in soured

Table 2 Analytical methods for the determination of inorganic sulfur species in aqueous mixtures

\begin{tabular}{|c|c|c|c|}
\hline Species detected & Detection & Detection limit & References \\
\hline $\mathrm{S}^{2-}, \mathrm{S}_{2} \mathrm{O}_{3}{ }^{2-}, \mathrm{SO}_{3}{ }^{2-}, \mathrm{SO}_{4}{ }^{2-}, \mathrm{S}_{4} \mathrm{O}_{6}{ }^{2-}$ & $\mathrm{CE}$, and direct and indirect UV (214 nm) & - & Saeed (2017) \\
\hline Total polythionates & Conductivity measurement & $0.04-2.28 \mathrm{~g} / 1$ & Montes-Rosua et al. (2016) \\
\hline $\begin{array}{l}\mathrm{SO}_{4}{ }^{2-}, \mathrm{SO}_{4}{ }^{2-}, \mathrm{S}_{2} \mathrm{O}_{3}{ }^{2-}, \mathrm{S}_{4} \mathrm{O}_{6}{ }^{2-}, \mathrm{S}_{5} \mathrm{O}_{6}{ }^{2-} \\
\mathrm{S}_{6} \mathrm{O}_{6}{ }^{2-}\end{array}$ & IC & $1-8 \mu \mathrm{mol} / \mathrm{kg}$ & Kaasalainen and Stefansson (2011) \\
\hline$S^{2-}$ & Titration and colorimetry & $0.02-52.7 \mathrm{mmol} / \mathrm{kg}$ & Kaasalainen and Stefansson (2011) \\
\hline $\mathrm{S}^{2-}, \mathrm{S}_{2} \mathrm{O}_{3}{ }^{2-}, \mathrm{SO}_{3}{ }^{2-}, \mathrm{SO}_{4}{ }^{2-}$ & $\mathrm{CE}$ & - & Lin et al. (2010) \\
\hline $\mathrm{S}_{2} \mathrm{O}_{3}{ }^{2-}, \mathrm{S}_{4} \mathrm{O}_{6}{ }^{2-}, \mathrm{S}_{5} \mathrm{O}_{6}{ }^{2-}, \mathrm{S}_{6} \mathrm{O}_{6}{ }^{2-}$ & IC & $0.05-1 \mu \mathrm{M}$ & Jeffrey and Brunt (2007) \\
\hline Polysulfides & HPLC and UV & $15-70 \mathrm{nM}$ & Kamyshny et al. (2006) \\
\hline $\mathrm{S}_{2} \mathrm{O}_{3}{ }^{2-}, \mathrm{S}_{4} \mathrm{O}_{6}{ }^{2-}, \mathrm{SO}_{3}{ }^{2-}, \mathrm{SO}_{4}{ }^{2-}, \mathrm{S}^{2-}$ & $\mathrm{CE}$ & - & Petre and Larachi (2006) \\
\hline $\mathrm{S}_{2} \mathrm{O}_{3}{ }^{2-}, \mathrm{SO}_{3}{ }^{2-}, \mathrm{SO}_{4}{ }^{2-}$ & $\mathrm{CE}$ & $0.45-1.0 \mu \mathrm{g} / 1$ & Liang (2001) \\
\hline $\mathrm{S}_{2} \mathrm{O}_{3}{ }^{2-}, \mathrm{S}_{4} \mathrm{O}_{6}{ }^{2-}, \mathrm{S}_{5} \mathrm{O}_{6}{ }^{2-}, \mathrm{S}_{6} \mathrm{O}_{6}{ }^{2-}$ & $\mathrm{CE}$, and direct and indirect UV (214 nm) & $5 \mathrm{mM}$ & Padarauskas et al. (2000) \\
\hline $\mathrm{S}_{2} \mathrm{O}_{3}{ }^{2-}, \mathrm{S}_{3} \mathrm{O}_{6}{ }^{2-}, \mathrm{S}_{4} \mathrm{O}_{6}{ }^{2-}, \mathrm{S}_{5} \mathrm{O}_{6}{ }^{2-}$ & IC and UV absorbance & $15-30 \mathrm{nM}$ & Miura and Kawaoi (2000) \\
\hline Polysulfides, $\mathrm{S}^{0}$ & Voltammetry & - & Rozan et al. (2000) \\
\hline$S^{2-}$ & Classical & $200-4000 \mathrm{ppb}$ & Pawlak and Pawlak (1999) \\
\hline $\mathrm{S}^{2-}, \mathrm{S}_{2} \mathrm{O}_{3}{ }^{2-}, \mathrm{SO}_{3}{ }^{2-}, \mathrm{SO}_{4}{ }^{2-}$ & ICP-MS & $35-270 \mu \mathrm{g} / 1$ & Divjak and Goessler (1999) \\
\hline $\mathrm{S}_{2} \mathrm{O}_{3}{ }^{2-}, \mathrm{SO}_{3}{ }^{2-}, \mathrm{SO}_{4}{ }^{2-}$ & Indirect and direct UV (214 and $254 \mathrm{~nm})$ & $0.17-0.5 \mathrm{mg} / \mathrm{l}$ & Hissner et al. (1999) \\
\hline$S^{2-}$ & IC & $0.14-16 \mathrm{ppb}$ & Miura et al. (1998) \\
\hline $\mathrm{S}_{2} \mathrm{O}_{3}{ }^{2-}, \mathrm{SO}_{3}{ }^{2-}, \mathrm{S}_{\mathrm{x}}{ }^{2-}$ & IC and UV (320 nm) & $\sim 0.1 \mu \mathrm{M}$ & Witter and Jones (1998) \\
\hline $\mathrm{S}^{2-}$ & $\mathrm{UV}-\mathrm{Vis}$ & $0.1-32 \mathrm{ppb}$ & Wall et al. (1997) \\
\hline $\mathrm{S}_{3} \mathrm{O}_{6}{ }^{2-}, \mathrm{S}_{4} \mathrm{O}_{6}{ }^{2-}, \mathrm{S}_{5} \mathrm{O}_{6}{ }^{2-}$ & UV (205 nm) & - & Weir et al. (1994) \\
\hline $\mathrm{S}^{2-}, \mathrm{S}_{2} \mathrm{O}_{3}{ }^{2-}, \mathrm{SO}_{3}{ }^{2-}, \mathrm{SO}_{4}{ }^{2-}, \mathrm{S}_{\mathrm{x}}{ }^{2-}$ & $\begin{array}{l}\text { Suppressed conductivity and UV } \\
(220 \mathrm{~nm})\end{array}$ & $4.9-68 \mu \mathrm{M}$ & Zhou et al. (1993) \\
\hline $\mathrm{S}_{2} \mathrm{O}_{3}{ }^{2-}, \mathrm{SO}_{3}{ }^{2-}, \mathrm{SO}_{4}{ }^{2-}$ & Suppressed conductivity & $15-75 \mu \mathrm{g} / 1$ & Weidenauer et al. (1996) \\
\hline$S^{2-}$ & Potentiometric & $3-32 \mathrm{ppm}$ & Raba et al. (1992) \\
\hline $\mathrm{S}_{2} \mathrm{O}_{3}{ }^{2-}, \mathrm{S}_{3} \mathrm{O}_{6}{ }^{2-}, \mathrm{S}_{4} \mathrm{O}_{6}{ }^{2-}, \mathrm{S}_{5} \mathrm{O}_{6}{ }^{2-}$ & $\begin{array}{l}\text { IC, suppressed conductivity, and amper- } \\
\text { ometry }\end{array}$ & $<1 \mu \mathrm{M}$ & Steudel and Holdt (1986) \\
\hline $\mathrm{S}_{2} \mathrm{O}_{3}{ }^{2-}, \mathrm{SO}_{3}{ }^{2-}, \mathrm{SO}_{4}{ }^{2-}$ & IC and UV (335 nm) & $0.05-0.1 \mathrm{mM}$ & Story (1983) \\
\hline
\end{tabular}


reservoirs, especially those undergoing seawater injection recovery processes which are common offshore. Furthermore, an assessment of the sulfur speciation is necessary for evaluating topsides handling of oil, gas, and produced water. Various separation techniques are available for determining sulfur anions in aqueous mixtures. Due to the rapid changes that could occur during the analysis of sulfur species, the selection of the proper analytical technique is important. The method used needs to be quick and reliable. Sample management is also important for the success of sulfur speciation studies.

Acknowledgements This work was made possible by the financial and technical support provided by Terra Nova and MITACS.

Open Access This article is distributed under the terms of the Creative Commons Attribution 4.0 International License (http://creativeco mmons.org/licenses/by/4.0/), which permits unrestricted use, distribution, and reproduction in any medium, provided you give appropriate credit to the original author(s) and the source, provide a link to the Creative Commons license, and indicate if changes were made.

\section{References}

Abou-Kassem JH (2000) Experimental and numerical modeling of sulfur plugging in carbonate reservoirs. J Pet Sci Eng 26:91-103

Adesina F, Churchil A, Olugbenga F (2012) Elemental sulfur induced formation damage management in gas reservoir. In: SPE 154980

Agrawal A, Vanbroekhoven K, Lal B (2010) Diversity of culturable sulfidogenic bacteria in two oil-water separation tanks in the north-eastern oil fields of India. Anaerobe 16, 8-12

Alekseev VI, Kiseleve OA, Levshina IV (1990) Role of the high pressure of hydrogen in the phenomenon of hydrogen sulfide corrosion cracking of steel. Sov Mater Sci 26:149-152

Amrani A, Zhang T, Ma Q, Ellis GS, Tang Y (2008) The role of labile sulfur compounds in thermochemical sulfate reduction. Geochim Cosmochim Acta 72:2960-2972

Anderson JH, Machel HG (1988) The Upper Devonian Nisku reef trend in central Alberta. Can Soc Pet Geol 13:391-398

Bandekar J, Sethna R, Kirschner M (1995) Quantitative determination of sulfur oxide species in white liquor by FT-IR. Appl Spectrosc 49:1577-1582

Barrett EL, Clark MA (1987) Tetrathionate reduction and production of $\mathrm{H}_{2} \mathrm{~S}$ from thiosulfate. Microbiol Rev 51:192-205

Barton LL, Fauque GD (2009) Biochemistry, physiology and biotechnology of sulfate-reducing bacteria. Adv Appl Microbiol 68:41-98

Belkin S, Wirsen CO, Jannasch HW (1985) Biological and abiological sulfur reduction at high temperatures. Appl Environ Microbiol 49:1057-1061

Bodtker G, Thorstenson T, Lillebo BL, Thorbjornsen BE, Ulvoen RH, Sunde E, Torsvik T (2008) The effect of long-term nitrate treatment on SRB activity, corrosion rate and bacterial community composition in offshore water injection systems. J Ind Microbiol Biotechnol 35:1625-1636

Bojes J, Lerbscher J, Wamburi W, Dilley C (2010) Elemental sulfur in 3-phase sour gas systems-is condensate really your ally? NACE, Alberta

Boulegue J, Lord CJ, Church T (1981) Sulfur speciation and associated trace metals $(\mathrm{Fe}, \mathrm{Cu})$ in the pore waters of Great Marsh, Delaware. Geochim Cosmochim Acta 46:453-464
Buchberger W, Haddad PR (1992) Effects of carrier electrolyte composition on separation selectivity in capillary zone electrophoresis of low-molecular-mass anions. J Chromatogr 608:59-64

Burger ED, Jenneman GE, Vedvik A, Bache O, Jensen TB, Soerensen S (2005) A mechanistic model to evaluate reservoir souring in the Etofisk field. In: SPE 93297

Burger ED, Jenneman GE, Caroll JJ (2013) On the partitioning of hydrogen sulfide in oilfield systems. In: SPE 164067

Casella IG, Guascito MR, Desimoni E (2000) Sulfide measurements by flow injection analysis and ion chromatography with electrochemical detection. Anal Chim Acta 409:27-34

Chapman JN, Beard HR (1973) Fast analytical procedure for the separation and determination of the polythionates found in Wackenroder's solution by high speed liquid chromatography. Anal Chem 45:2268-2270

Chen KY, Morris JC (1972) Kinetics of oxidation of aqueous sulfide by oxygen. Environ Sci Technol 6:529-537

Chen T, He Q, Lu H, Peng P, Liu J (2009) Thermal simulation experiments of saturated hydrocarbons with calcium sulfate and element sulfur: Implications on origin of $\mathrm{H}_{2} \mathrm{~S}$. Sci China Ser D Earth Sci 52:1550-1558

Chernik PS, Williams PJ (1993) Extended production testing of the Bearberry ultra-sour gas resource. In: SPE 26190

Ciesielski W, Zlobinska U, Krenc A (2001) Iodimetric determination of tetrathionate and simultaneous determination of thiosulfate and tetrathionate. Chem Anal (Warsaw) 46:397-401

Ciglenečki I, Marguš M, Bura-Nakić E, Milanović I (2014) Electroanalytical methods in characterization of sulfur species in aqueous environment. J Electrochem Sci Eng 4:155-163

Clark PD, Hyne JB, Tyrer JD (1983) Chemistry of organosulfur compound types occurring in heavy oil sands 1 . High temperature hydrolysis and thermolysis of tetrahydrothiophene in relation to steam stimulation processes. Fuel 62:959-962

Clark PD, Hyne JB, Tyrer JD (1984b) Some chemistry of organosulphur compound types occurring in heavy oil sands: 2 . Influence of $\mathrm{pH}$ on the high temperature hydrolysis of tetrahydrothiophene and thiophene. Fuel 63:125-128

Corr JJ, Anacleto JF (1996) Analysis of inorganic species by capillary electrophoresis-mass spectrometry and ion exchange chromatography-mass spectrometry using an ion spray source (crystal). Anal Chem 68:2155-2163

Dalsgaard T, Bak F (1994) Nitrate reduction in a sulfatereducing bacterium, Desulfovibrio desulfuricans, isolated from rice paddy soil: sulphide inhibition, kinetics, and regulation. Appl Environ Microbiol 60:291-297

Daunoravicius Z, Padarauskas A (2002) Capillary electrophoretic determination of thiosulfate, sulfide and sulfite using in-capillary derivation with iodine. Electrophoresis 23:2439-2444

Divjak B, Goessler W (1999) Ion chromatographic separation of sulfur-containing inorganic anions with an ICP-MS as element-specific detector. J Chromatogr A 844:161-169

Dolfing J, Hubert CRJ (2017) Using thermodynamics to predict the outcomes of nitrate-based oil reservoir souring control interventions. Front Microbiol 8:1-9

Dowling NI (1992) Corrosion of materials used in storage and handling of solid elemental sulfur, materials performance: sulfur and energy. In: Proceedings of an international conference

Dronen K, Roalkvam I, Beeder J, Torsvik T, Steen IH, Skauge A, Liengen T (2014) Modeling of heavy nitrate corrosion in anaerobe aquifer injection water biofilm: a case study in a flow rig. Environ Sci Technol 48:8627-8635

Druschel GK, Schoonen MAA, Nordstrom K, Ball JW, Xu Y, Cohn CA (2003) Sulfur geochemistry of hydrothermal waters in Yellowstone National Park, Wyoming, USA. III. An anionexchange resin technique for sampling and preservation of sulfoxyanions in natural waters. Geochem Trans 4:12-19 
Eden B, Laycock PJ, Fielder M (1993) Oilfiled reservoir souring. Offshore Technology Report, OTH 92385

Fang H, Brown B, Young D, Nesic S (2011) Investigation of elemental sulfur corrosion mechanisms, Corrosion, NACE international, paper no. 11398

Gieg L, Jack T, Foght J (2011) Biological souring and mitigation in oil reservoirs. Appl Microbiol Biotechnol 92:263-282

Goldhaber MB, Orr WL (1995) Kinetic controls on thermochemical sulfate reduction as a source of sedimentary $\mathrm{H}_{2} \mathrm{~S}$. In: Geochemical transformations of sedimentary sulfur. ACS symposium series

Goldstein TP, Aizenshtat Z (1994) Thermochemical sulfate reduction, a review. J Therm Anal 42:241-290

Green SA, Blough NV (1994) Optical absorption and fluorescence properties of chromophoric dissolved organic matter in natural waters. Limnol Oceanogr 39:1903-1916

Grigoryan AA, Cornish SL, Buziak B, Lin S, Cavallaro A, Arensdorf JJ, Voordouw G (2008) Competitive oxidation of volatile fatty acids by sulfate- and nitrate-reducing bacteria from an oil field in Argentina. Appl Environ Microbiol 74:4324-4335

Guenther EA, Johnson KS, Coale KH (2001) Direct ultraviolet spectrophotometric determination of total sulfide and iodide in natural waters. Anal Chem 73:3481-3487

Haddad PR, Philip D, Miroslav M (1999) Developments in sample preparation and separation techniques for the determination of inorganic ions by ion chromatography and capillary electrophoresis. J Chromatogr A 856:145-177

Harris DC (2010) Quantitative chemical analysis, 8th edn. W. H. Freeman and Company, New York

Heydari E, Moore CH (1989) Burial diagenesis and thermochemical sulfate reduction, Smackover Formation, southeastern Mississippi salt basin. Geology 17:1080-1084

Hissner F, Mattusch J, Heinig K (1999) Quantitative determination of sulfur-containing anions in complex matrices with capillary electrophoresis and conductivity detection. J Chromatogr A 848:503-513

Hoffmann GG, David T (2018) Aquathrmolysis of organic compounds in the presence of $\mathrm{H}_{2} \mathrm{~S}$ and sulfate. https://web.anl. gov/PCS/acsfuel/preprint\%20archive/Files/42_2_SAN\%20 FRANCISCO_04-97_0772.pdf

Holubnyak Y, Bremer JM, Hamling JA, Huffman BL, Mibeck B, Klapperich RJ, Smith SA, Sorensen JA, Harju JA (2011) Understanding the Souring at bakken oil reservoirs. In: SPE, pp 141434

Hubert C (2010) Microbial ecology of oil reservoir souring and its control by nitrate injection. In: Timmis KN (ed) Handbook of hydrocarbon and lipid microbiology. Springer, Berlin, Heidelberg, pp 2753-2766

Hubert C, Nemati M, Jenneman G, Voordouw G (2005) Corrosion risk associated with microbial souring control using nitrate or nitrite. Appl Microbiol Biotechnol 68:272-282

Hutcheon I (1998) The potential role of pyrite oxidation in corrosion and reservoir souring. J Can Pet Technol 37:27-31

Hutcheon I, Krouse HR, Abercrombie HJ (2009) Controls on the origin and distribution of elemental sulfur, $\mathrm{H}_{2} \mathrm{~S}$, and $\mathrm{CO}_{2}$ in paleozoic hydrocarbon reservoirs in western Canada. In: Geochemical transformations of sedimentary sulfur. ACS symposium series

Jeffrey MI, Brunt SD (2007) The quantification of thiosulfate and polythionates in gold leach solutions and on anion exchange resins. Hydrometallurgy 89:52-60

Jeroschewski P, Steuckart C, Kühl M (1996) An amperometric microsensor for the determination of $\mathrm{H}_{2} \mathrm{~S}$ in aquatic environments. Anal Chem 68:4351-4357

Johnston SL, Cunningham G, Voordouw G, Jack TR (2010) Sulfurreducing bacteria may lower corrosion risk in oil fields by coupling oxidation of oil organics to reduction of sulfur-polysulfide to sulfide, Corrosion, NACE International, paper no. 10254

Jorgensen BB (1990) A thiosulfate shunt in the sulfur cycle of marine sediments. Science 249:152-154

Kaasalainen H, Stefansson A (2011) Sulfur speciation in natural hydrothermal waters, Iceland. Geochim Cosmochim Acta 75:2777-2791

Kamyshny A, Ekeltchik I, Gun J, Lev O (2006) Method for the determination of inorganic polysulfide distribution in aquatic systems. Anal Chem 78:2631-2639

Kariuki S, Morra MJ, Umiker KJ, Cheng IF (2001) Determination of total ionic polysulfides by differential pulse polarography. Anal Chim Acta 442:277-285

Kaster KM, Grigoriyan A, Jenneman G, Voordouw G (2007) Effect of nitrate and nitrite on sulfide production by two thermophilic, sulfate-reducing enrichments from an oil field in the North Sea. Appl Microbiol Biotechnol 75:195-203

Katz DL (1959) Handbook of natural gas engineering. McGraw-Hill, New York

Kaur G, Mandal AK, Nihlani MC, Lal B (2009) Control of sulfidogenic bacteria in produced water from the Kathloni oilfield in northeast India. Int Biodeterior Biodegrad 63:151-155

Khatib ZI, Salanitro JR (1997) Reservoir souring: analysis of surveys and experience in sour waterfloods. In: Society of Petroleum Engineers. In: SPE-38795

King MB, Al-Najjar H (1977) The solubilities of carbon dioxide, hydrogen sulphide and propane in some normal alkane solvents-I: experimental determinations in the range $15-70{ }^{\circ} \mathrm{C}$ and comparison with ideal solution values. Chem Eng Sci 32:1241-1246

Kiyosu Y, Krouse HR (1990) The role of organic acid in the abiogenic reduction of sulfate and the sulfur isotope effect. Geochem J 24:21-27

Koh T (1990) Analytical chemistry of polythionates and thiosulfate: a review. Anal Sci 6:3-14

Krouse HR, Viau CA, Eliuk LS, Ueda A, Halas S (1988) Chemical and isotopic evidence of thermochemical sulphate reduction by light hydrocarbon gases in deep carbonate reservoirs. Nature 333:415-419

Kumaraswamy R, Ebert S, Gray MR, Fedorak PM, Foght JM (2011) Molecular- and cultivation-based analyses of microbial communities in oil field water and in microcosms amended with nitrate to control $\mathrm{H}_{2} \mathrm{~S}$ production. Appl Microbiol Biotechnol 89:2027-2038

Kuyucak N, Yaschyshyn D (2007) Managing thiosalts in mill effluents, "Studies conducted at the Kidd metallurgical site". In: Mining and the environment IV conference, Ontario, Canada

Lawrence NS, Davis J, Compton RG (2000) Analytical strategies for the detection of sulfide: a review. Talanta 52:771-784

Liang H (2001) Method development and validation for the determination of various sulfur-containing anions and other anions in the corrosion process by capillary ion electrophoresis with indirect detection. J Chromatogr Sci 39:12-20

Ligthelm DJ, de Boer RB, Brint JF, Schulte WM (2000) Analytical strategies for the detection of sulfide: a review. Talanta 52:771784 (SPE 23141)

Lin YT, Liu YW, Cheng YJ, Huang HY (2010) Analyses of sulfonamide antibiotics by a successive anion- and cation-selective injection coupled to microemulsion electrokinetic chromatography. Electrophoresis 31:2260-2266

Lysnes K, Bodtker G, Torsvik T, Bjornestad EO, Sunde E (2009) Microbial response to reinjection of produced water in an oil reservoir. Appl Microbiol Biotechnol 83:1143-1157

Machel HG (1987) Some aspects of diagenetic sulphate-hydrocarbon redox reactions. Geol Soc Lond Spec Publ 36:15-28

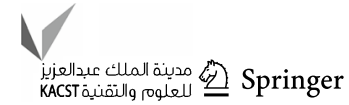


Machel HG (1992) Low-temperature and high-temperature origins of elemental sulfur in diagenetic environments. In: Wessel GR, Wimberly BH (eds) Native sulfur-developments in geology and exploration. Society for mining, metallurgy, and exploration, $\mathrm{pp}$ 3-22

Machel HG, Krouse HR, Sassen R (1995) Products and distinguishing criteria of bacterial and thermochemical sulfate reduction. Applied Geochemistry 10:373-389

Machel HG (2001) Bacterial and thermochemical sulfate reduction in diagenetic settings-old and new insights. Sediment Geol 140:143-175

Makhija R, Hitchen A (1978) Determination of polythionates and thiosulphate in mining effluents and mill circuit solutions. Talanta 25:79-84

Marcano N, Larter S, Snowdon L, Bennett B (2013) An overview of the origin, pathways and controls of $\mathrm{H}_{2} \mathrm{~S}$ production during thermal recovery operations of heavy and extra-heavy oil. In: Integration, GeoConvention

Marsland SD, Dawe RA, Kelsall GH (1989) Inorganic chemical souring of oil reservoirs. In: SPE, pp 18480

Martin RL (2008) Corrosion consequences of nitrate/nitrite additions to oilfield brines. SPE J Pet Tech 114923:1-8

Millero FJ (1986) The thermodynamics and kinetics of the H2S system in natural waters. Mar Chem 18:121-147

Miranda-Trevino JC (2013) The importance of thiosalt speciation in the management of tailing ponds, Memorial University of Newfoundland

Miranda-Trevino JC, Pappoe M, Hawboldt K, Bottaro C (2013) The importance of thiosalts speciation: review of analytical methods, kinetics, and treatment. Crit Rev Environ Sci Technol 43:2013-2070

Miura Y, Kawaoi A (2000) Determination of thiosulfate, thiocyanate and polythionates in a mixture by ionpair chromatography with ultraviolet absorbance detection. J Chromatogr A 884:81-87

Miura Y, Watanabe M (2001) Ion-pair chromatography of polythionates and thiosulfate with detection based on their catalytic effects on the postcolumn azide-iodine reaction. J Chromatogr A 920:163-171

Miura Y, Kitamura H, Koh T (1991) Spectrophotometric determination of micro amounts of tetrathionate via its oxidation with permanganate. Microchim Acta 103:235-243

Miura Y, Fukasawa K, Koh T (1998) Determination of sulfur anions at the ppb level by ion chromatography utilizing their catalytic effects on the postcolumn reaction of iodine with azide. J Chromatogr A 804:143-150

Montes-Rosua C, Iglesias-Gonzalez N, Romero R, Mazuelos A, Carranza F (2016) Monitoring polythionate bio-oxidation by conductivity measurement. Miner Eng 95:40-47

Morse JW, Millero FJ, Cornwell JC, Rickard D (1987) The chemistry of the hydrogen sulfide and iron sulfide systems in natural waters. Earth Sci Rev 24:1-42

Moses CO, Nordstrom DK, Mills AL (1984) Sampling and analysing mixtures of sulphate, sulphite, thiosulphate and polythionate. Talanta 31:331-339

Moses CO, Nordstorm DK, Herman JS, Mills AL (1987) Aqueous pyrite oxidation by dissolved oxygen and by ferric iron. Geochim Cosmochim Acta 51:1561-1571

Motellier S, Descostes M (2001) Sulfur speciation and tetrathionate sulfitolysis monitoring by capillary electrophoresis. J Chromatogr A 907:329-335

Moura I, Bursakov S, Costa C, Moura JJG (1997) Nitrate and nitrite utilization in sulphate-reducing bacteria. Anaerobe 3:279-290

Muyzer G, Stams AJM (2008) The ecology and biotechnology of sulphate-reducing bacteria. Nat Rev Microbiol 6:441-454
Myhr S, Lillebo BLP, Sunde E, Beeder J, Torsvik T (2002) Inhibition of microbial $\mathrm{H}_{2} \mathrm{~S}$ production in an oil reservoir model column by nitrate injection. Appl Microbiol Biotechnol 58:400-408

Nemati M, Jenneman GE, Voordouw G (2001) Impact of nitratemediated microbial control of souring in oil reservoirs on the extent of corrosion. Biotechnol Prog 17:852-859

Noth $\mathrm{S}$ (1997) High $\mathrm{H}_{2} \mathrm{~S}$ contents and other effects of thermochemical sulfate reduction in deeply buried carbonate reservoirs: a review. Geol Rundsch 86:275-287

O'Reilly JW, Dicinoski GW, Shaw MJ, Haddad PR (2001) Review: chromatographic and electrophoretic separation of inorganic sulfur and sulfur-oxygen species. Anal Chim Acta 432:165-192

O'Reilly JW, Dicinoski GW, Miura Y, Haddad PR (2003) Separation of thiosulfate and the polythionates in gold thiosulfate leach solutions by capillary electrophoresis. Electrophoresis 24:2228-2234

Orphan VJ, Taylor LT, Hafenbradl D, Delong EF (2000) Culturedependent and culture-independent characterization of microbial assemblages associated with high-temperature petroleum reservoirs. Appl Environ Microbiol 66:700-711

Orr WL (1977) Geologic and geochemical controls on the distribution of $\mathrm{H}_{2} \mathrm{~S}$ in natural gas. In: Advances in organic geochemistry. Enadisma, Madrid, pp 571-597

Padarauskas A, Paliulioyte V, Ragauskas R, Dikcius A (2000) Capillary electrophoretic determination of thiosulfate and its oxidation products. J Chromatogr A 879:235-243

Pappoe M, Bottaro CS (2014) Systematic optimization of a pyromellitic acid background electrolyte for capillary electrophoresis with indirect $\mathrm{UV}-\mathrm{Vis}$ detection and online pre-concentration analysis of thiosalt anions in treated mine tailings. Anal Methods 6:9305-9312

Pawlak Z, Pawlak AS (1999) Modification of iodometric determination of total and reactive sulfide in environmental samples. Talanta 48:347-353

Peters E (1976) Direct leaching of sulfides: chemistry and applications. Metall Trans B 7:505-517

Petre CF, Larachi F (2006) Capillary electrophoretic separation of inorganic sulfur-sulfide, polysulfides, and sulfur-oxygen species. J Sep Sci 29:144-152

Raba J, Mallea MA, Quintar S, Cortinez VA (1992) Determination of sulfide with chloranilic acid by biamperometric and automatic potentiometric end-point detection with a lead chloranilate selective electrode. Talanta 39:1007-1011

Ramo J, Sillanpaa M (2003) Interactions between polysulphides and stainless steel materials. Mater Corros 54:37-39

Reid ML, Warren LA (2016) S reactivity of an oil sands composite tailings deposit undergoing reclamation wetland construction. J Environ Manag 166:321-329

Rickard D, Schoonen MAA, Luther GW III (1995) Chemistry of iron sulfides in sedimentary environments. In: ACS symposium series

Rimstidt JD, Vaughan DJ (2003) Pyrite oxidation: a state-of-the-art assessment of the reaction mechanism. Geochim Cosmochim Acta 67:873-880

Roberts BE (1997) The effect of sulfur deposition on gas well inflow performance. In: SPE 36707

Rozan TF, Theberge SM, Luther GW (2000) Quantifying elemental sulfur (S), bisulfide $\left(\mathrm{HS}^{-}\right)$and polysulfides $\left(\mathrm{S}_{2-\mathrm{x}}\right)$ using a voltammetric method. Anal Chim Acta 415:175-184

Saeed AH (2017) Analysis of sulfide and sulfur oxyanions in water and wastewater using capillary zone electrophoresis with detection by indirect and direct UV-Vis spectrophotometry. M.Sc. Thesis. Memorial University

Safizadeh F, Larachi F (2014) Speciation of sulfides and cyanicides in the cyanidation of precious metal bearing ores using capillary electrophoresis. Instrum Sci Technol 42:215-229 
Sakamoto-Arnold CM, Johnson KS, Beehler CL (1986) Determination of hydrogen sulfide in seawater using flow injection analysis and flow analysis. Limnol Oceanogr 31:894-900

Sassen R (1988) Geochemical and carbon isotopic studies of crude oil destruction, bitumen precipitation, and sulfate reduction in the deep Smackover Formation. Org Geochem 12:351-361

Schippers A, Sand W (1999) Bacterial leaching of metal sulfides proceeds by two indirect mechanisms via thiosulfate or via polysulfides and sulfur. Appl Environ Microbiol 65:319-321

Schippers A, Jozsa PE, Sand W (1996) Sulfur chemistry in bacterial leaching of pyrite. Appl Environ Microbiol 62:3424-3431

Schofield M, Stott J (2012) Assessing the magnitude and consequences of reservoir souring. J Petrol Technol 64:76-79

Seto CJ, Beliveau DA (2000) Reservoir souring in the caroline field. In: SPE-59778

Shedid SA, Zekri AY (2002) Formation damage due to sulfur deposition in porous media. In: SPE-73721

Standing MB (1977) Volumetric and phase behavior of oil field hydrocarbon systems. Society of Petroleum Engineers of AIME

Stemler P (2012) Subsurface control of $\mathrm{H}_{2} \mathrm{~S}$ with nitrate, nitrite and $\mathrm{H}_{2} \mathrm{~S}$ Scavenger, Suncor Energy, E \& P East Coast, Terra Nova

Stetter KO, Huber R, Blochl E, Kurr M, Eden RD, Fielder M, Cash H, Vance I (1993) Hyperthermophilic archaea are thriving in deep North Sea and Alaskan oil reservoirs. Nature 365:743-745

Steudel R (1996) Mechanism for the formation of elemental sulfur from aqueous sulfide in chemical and microbiological desulfurization processes. Ind Eng Chem Res 35:1417-1423

Steudel R, Holdt G (1986) Ion-pair chromatographic separation of polythionates $\mathrm{SnO}_{6}{ }^{2-}$ with up to thirteen sulphur atoms. J Chromatogr A 361:379-384

Story JN (1983) High speed LC of sulfur anions with sulfur selective detection. J Chromatogr Sci 21:272-277

Sturman PJ, Goeres DM (1999) Control of hydrogen sulfide in oil and gas wells with nitrite injection. In: SPE 56772

Sunde E, Thorstenson T, Torsvik T, Vaag JE, Espedal MS (1993) Fieldrelated mathematical model to predict and reduce reservoir souring. In: SPE 25197

Sunde E, Lillebo BLP, Thorstenson T (2004) $\mathrm{H}_{2} \mathrm{~S}$ inhibition by nitrate injection on the Gullfaks field, corrosion, NACE International, paper no. 04760

Takano B, Watanuki K (1998) Quenching and liquid chromatographic determination of polythionates in natural water. Talanta 35:847-854

Takano B, Ohsawa S, Glover RB (1994) Surveillance of Ruapehu Crater Lake, New Zealand, by aqueous polythionates. J Volcanol Geotherm Res 60:29-57

Tang D, Santschi PH (2000) Sensitive determination of dissolved sulfide in estuarine water by solid-phase extraction and highperformance liquid chromatography of methylene blue. J Chromatogr A 883:305-309

Tang K, Baskaran V, Nemati M (2009) Bacteria of the sulphur cycle: An overview of microbiology, biokinetics and their role in petroleum and mining industries. Biochem Eng J 44:73-94

Toland WG (1960) Oxidation of organic compounds with aqueous sulfate. J Am Chem Soc 82:1911-1916

Tyrie JJ, Ljosland E (1993) Predicted increase in Gullfaks H2S production associated with injected sea water-application of biofilm model. SPE 26700

Videla HA, Herrera LK (2005) Microbiologically influenced corrosion: looking to the future. Int Microbiol 8:169-180

Voordouw G, Buziak B, Lin S, Grigoriyan A, Kaster KM, Jenneman GE, Arensdorf JJ (2007) Use of nitrate or nitrite for the management of the sulfur cycle in oil and gas fields. In: SPE 106288

Voordouw G, Grigoryan AA, Lambo A, Lin S, Park HS, Jack TR, Coombe D, Clay B, Zhang F, Ertmoed R, Miner K, Arensdorf JJ (2009) Sulfide remediation by pulsed injection of nitrate into a low temperature Canadian heavy oil reservoir. Environ Sci Technol 43:9512-9518

Wall J, Chiswell B, Hamilton B, Dieckmann C, O’Halloran K (1997) Analysis for sulfur as hydrogen sulfide incorporating zirconia pretreatment and preconcentration. Talanta 45:85-90

Wang Y, Wang F, Jin F, Jing Z (2013) Effects of metals and $\mathrm{Ni}_{3} \mathrm{~S}_{2}$ on reactions of sulfur species $\left(\mathrm{HS}^{-}, \mathrm{S}\right.$, and $\mathrm{S}_{2} \mathrm{O}_{3}{ }^{2-}$ ) under alkaline hydrothermal conditions. Ind Eng Chem Res 52:5616-5625

Warren LA, Norlund KLI, Bernier L (2008) Microbial thiosulphate reaction arrays: the interactive roles of $\mathrm{Fe}(\mathrm{III}), \mathrm{O}_{2}$ and microbial strain on disproportionation and oxidation pathways. Geobiology 6:461-470

Wei L, Ma F, Zhao G (2010) Composition and dynamics of sulfatereducing bacteria during the waterflooding process in the oil field application. Bioresour Technol 101:2643-2650

Weidenauer M, Hoffmann P, Lieser KH (1996) Separation and determination of $\mathrm{S}$-anions in very small samples by microbore ion chromatography. Anal Bioanal Chem 342:333-336

Weir SI, Butler ECV, Haddad PR (1994) Ion chromatography with UV detection for the determination of thiosulfate and polythionates in saline waters. J Chromatogr A 671:197-203

Wilhelms A, Larter SR, Head I, Farrimond P, di-Primio R, Zwach C (2001) Biodegradation of oil in uplifted basins prevented by deep-burial sterilization. Nature 411:1034-1037

Wilkin RT, Barnes HL (1996) Pyrite formation by reactions of iron monosulfides with dissolved inorganic and organic sulfur species. Geochim Cosmochim Acta 60:4167-4179

Witter AE, Jones AD (1998) Comparison of methods for inorganic sulfur speciation in a petroleum production effluent. Environ Toxicol Chem 17:2176-2184

Worden RH, Smalley PC, Oxtoby NH (1995) Gas souring by thermochemical sulfate reduction at $140{ }^{\circ} \mathrm{C}$. AAPG Bull 79:854-863

Worden RH, Smalley PC, Oxtoby NH (1996) The effects of thermochemical sulfate reduction upon formation water salinity and oxygen isotopes in carbonate gas reservoirs. Geochim Cosmochim Acta 60:3925-3931

Worden RH, Smalley PC, Cross MM (2000) The influence of rock fabric and minerology on thermochemical sulfate reduction: Khuff formation, Abu Dhabi. J Sediment Res 70:1210-1221

$\mathrm{Xu}$ Y, Schoonen MAA (1995) The stability of thiosulfate in the presence of pyrite in low-temperature aqueous solutions. Geochim Cosmochim Acta 59:4605-4622

$\mathrm{Xu}$ Y, Schoonen MAA, Nordstrom DK, Cunningham KM, Ball JW (2000) Sulfur geochemistry of hydrothermal waters in Yellowstone National Park, Wyoming, USA. II. Formation and decomposition of thiosulfate and polythionate in Cinder Pool. J Volcanol Geotherm Res 97:407-423

Yuan S, Chou IM, Burruss RC, Wang X, Li J (2013) Disproportionation and thermochemical sulfate reduction reactions in $\mathrm{S}-\mathrm{H}_{2} \mathrm{O}-$ $\mathrm{CH}_{4}$ and $\mathrm{S}-\mathrm{D}_{2} \mathrm{O}-\mathrm{CH}_{4}$ systems from 200 to $340{ }^{\circ} \mathrm{C}$ at elevated pressures. Geochim Cosmochim Acta 118:263-275

Zhang H, Jeffrey MI (2010) A kinetic study of rearrangement and degradation reactions of tetrathionate and trithionate in near-neutral solutions. Inorg Chem 49:10273-10282

Zhang JZ, Millero FJ (1991) The rate of sulfite oxidation in seawater. Geochim Cosmochim Acta 5:677-685

Zhang JZ, Millero FJ (1993) The products from the oxidation of $\mathrm{H}_{2} \mathrm{~S}$ in seawater. Geochim Cosmochim Acta 57:1705-1718

Zhang T, Ellis GS, Wang K, Walters CC, Kelemen SR, Gillaizeau B, Tang Y (2007) Effect of hydrocarbon type on thermochemical sulfate reduction. Org Geochem 38:897-910

Zhang T, Amrani A, Ellis GS, Ma Q, Tang Y (2008) Experimental investigation on thermochemical sulfate reduction by $\mathrm{H}_{2} \mathrm{~S}$ initiation. Geochim Cosmochim Acta 72:3518-3530

Zhang S, Jin F, Zeng X, Hu J, Huo Z, Wang Y, Watanabe N, Hirano N, Tsuchiya N (2011) Effects of general zero-valent metals

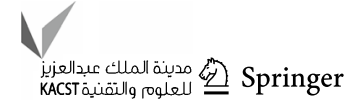


power of $\mathrm{Co} / \mathrm{W} / \mathrm{Ni} / \mathrm{Fe}$ on hydrogen production with $\mathrm{H}_{2} \mathrm{~S}$ as a reductant under hydrothermal conditions. Int J Hydrogen Energy 36:8878-8884

Zhou X, Wang S, Wang Z, Jiang M (1993) Electrocatalytic oxidation of thiosulfate on a modified nickel hexacyanoferrate film electrode. Fresenius' J Anal Chem 345:424-427

Zopfi J, Ferdelman TG, Fossing H (2004) Distribution and fate of sulfur intermediates-sulfite, tetrathionate, thiosulfate, and elemental sulfur-in marine sediments. In: Amend JP, Edwards
KJ, Lyons TW (eds) Sulfur Biogeochemistry—past and present. Geological Society of America, Colorado, pp 97-116

Publisher's Note Springer Nature remains neutral with regard to jurisdictional claims in published maps and institutional affiliations. 